\title{
Development of an autochthonous starter culture for spreadable goat cheese
}

\author{
Florencia FRAU ${ }^{1 \star}$, Martha NUÑEZ², Luciana GEREZ², Nora PECE ${ }^{1}$, Graciela FONT²
}

\begin{abstract}
The aim of this work was to select strains of LAB autochthonous from Santiago del Estero to formulate a starter culture for making spreadable goat cheese. Four strains were selected: CRL1799 (Lactobacillus fermentum with high acidifying activity), CRL1803 (Lactobacillus fermentum with high proteolytic activity), CRL1808 (Lactobacillus rhamnosus with production of exopolysaccharide) and CRL1785 (Enterococcus faecium with diacetyl-acetoin production). The selected strains showed qualities that make them useful as starter culture in the elaboration of spreadable cheese. This starter culture is an alternative that allows obtaining differentiated products. The inclusion of CRL1808 strains seems to improve the rheology and texture, excluding the use of additives.
\end{abstract}

Keywords: lactic acid bacteria; autochthonous starter culture; spreadable goat cheese; biochemical activities.

Practical Application: This research presents a novel autochthonous starter culture to be used in the elaboration of spreadable goat cheese. The inclusion of exopolysaccharide producing strain clearly improved the rheology and texture of spreadable cheese and it is possible to obtain the expected textural characteristics, without the incorporation of additives.

\section{Introduction}

Argentina is one of the larger caprine producers in South America with about 4,250,000 goats mainly distributed in 3 provinces: Santiago del Estero (17.4\%), Neuquén (16.7\%) and Mendoza (16.6\%) (Agroalimentos Argentinos II). However, the goat industry did not reached a large commercial development, since it has been affected by continuous regional fluctuations of the economy. The goat milk is mostly processed into cheeses in the north and central regions of Argentina. Thus, cheese manufacturing is the main activity in goat dairies ( $200 \mathrm{t}$ cheese/year).

Goat milk microbiota is essential for the manufacture of cheeses, conferring them particular and distinctive flavors and generating high value-added products. Commonly, for the manufacture of goat cheese, cow milk lactic commercial starters are used. The use of such starter cultures is partially responsible for the loss of the biodiversity in the microbiota participating in the manufacture, and of the typical and exclusive organoleptic properties (Nieto-Arribas et al., 2009).

In the manufacture of goat cheese, selection of adequate starter or adjunct cultures is crucial. Several technological properties are very important, such as acidification rate, diacetyl production, protease, lipase activities and citrate-fermentative ability. These different metabolic activities allow the use of some strains for the manufacture of cheeses with distinctive flavor characteristics (El Soda et al., 2003).

The spreadable cheeses are characterized by a soft, creamy paste and an elastic texture. The rheological properties of this product play a determining role in the consumer acceptance, so it is important to include either chemical stabilizers such as gums, gelatin or other thickener food additives. An interesting option, which has not yet been studied in depth, is the use of exopolysaccharides (EPS) produced by lactic acid bacteria (LAB). Exopolysaccharides of lactic origin are important because of their potential applications in food industries such as texturizers, viscosifiers, emulsifiers and syneresis-lowering agents, for their pseudoplastic rheological behavior and water binding capacity (Kodali et al., 2009).

The present work evaluates the technological properties and metabolic activities of LAB isolated from goat milk and goat cheeses for the development of an autochthonous starter culture for use in the manufacture of spreadable goat cheese. The effect of different mixed autochthonous starter cultures on the microbiological, rheological and sensory profiles of experimental models of spreadable goat cheese was also studied.

\section{Materials and methods}

\subsection{Micro-organisms and culture conditions}

Sixty-six strains of LAB isolated from goat cheese and milk of Santiago del Estero (Argentina) and belonging to the Culture Collection of Centro de Referencia para Lactobacilos (CERELA, Tucumán, Argentina) were studied: twenty-nine lactobacilli and thirty-seven lactococci. Cultures were grown in MRS broth (to lactobacilli, Britania, Buenos Aires, Argentina) or LAPTg (to lactococci, Raibaud et al., 1973) at $37^{\circ} \mathrm{C}$ for $8 \mathrm{~h}$.

${ }^{1}$ Facultad de Agronomía y Agroindustrias - FAyA, Universidad Nacional de Santiago del Estero - UNSE, Santiago del Estero, Argentina

${ }^{2}$ Centro de Referencia para Lactobacilos - CERELA-CONICET, Tucumán, Argentina

*Corresponding author: ffrau@unse.edu.ar 


\subsection{Technological properties and metabolic activities of LAB}

\section{Acidifying activity}

The acidifying activity of strains was evaluated in sterile goat milk by visual observation and determination of final $\mathrm{pH}$ after incubation for 16 and $24 \mathrm{~h}$ at $37^{\circ} \mathrm{C}$. The $\mathrm{pH}$ was determined using an Altronix TP IX pH meter (Altronix Corporation, Brooklyn, New York, USA). The LAB were categorized as strains with fast (milk coagulation $<16 \mathrm{~h}$ ) or slow (milk coagulation $>16 \mathrm{hs)}$ (Blanco et al., 1978; Sandine, 1979).

\section{Proteolytic activity}

Proteolytic activity of strains was determined by the o-phthaldialdehyde (OPA) test (Church et al., 1983). Samples $\left(16 \mathrm{~h}\right.$ at $37^{\circ} \mathrm{C}$ ) were incubated with $0.75 \mathrm{M}$ trichloroacetic acid (Sigma Chemical Co.) at a sample: TCA ratio $=1: 3$ at $4{ }^{\circ} \mathrm{C}$ for $30 \mathrm{~min}$ and centrifuged (5000 rpm, $10 \mathrm{~min})$. A $10 \mu \mathrm{L}$ supernatant aliquot of this mixture was added to $0.2 \mathrm{~mL}$ of OPA reagent and incubated at room temperature for $20 \mathrm{~min}$; OD at $340 \mathrm{~nm}$ was read in a spectrophotometer. A standard curve was prepared using glycine; the results were expressed as $\mathrm{mM}$ of glycine/L of milk. The LAB were categorized as strains with high $(>4.0 \mathrm{mM}$ glycine), median (from 4 to $1.0 \mathrm{mM}$ glycine) and low activity (<1.0 mM glycine) .

\section{Diacetyl-acetoin production}

The production of diacetyl-acetoin was determined as described by Barritt (1936). Cultures were grown in goat milk for $24 \mathrm{~h}$ at $37^{\circ} \mathrm{C}$. To1 $\mathrm{mL}$ of fermented sample was added $0.5 \mathrm{~mL}$ of $\alpha$-naphthol ( $5 \mathrm{~g}$ of $\alpha$-naphthol in $100 \mathrm{~mL}$ of 95 per cent ethyl alcohol) and $0.2 \mathrm{~mL}$ of $\mathrm{KOH} /$ creatine (40\%/0.3\% ration). A positive reaction was characterized by an intense orange band developing in a few seconds from 5 to 10 minutes after the addition of reagents. The LAB were categorized as strains with high (band orange coloration), low production (band yellow coloration) and negative (no band).

\section{Citrate utilization}

The use of citrate as energy source was determined by the methodology described by Galeslod et al. (1961). A clear zone around the colonies indicated the ability to use citrate.

\section{Lipolytic activity}

The lipolytic activity was determined by the agar diffusion assay (Jaeger \& Eggert, 2002). The strains were plated on agar plates containing $1.5 \% \mathrm{w} / \mathrm{v}$ agar-agar ultra-pure (Merck, Darmstadt, Germany), 0.25\% v/v triglycerides (triacetin, tributyrin, tricaprylin, trilauryl, $0.02 \% \mathrm{w} / \mathrm{v}$ sodium azide, and $100 \mathrm{mmol} / \mathrm{L}$ sodium phosphate buffer ( $\mathrm{pH} 7.00$ ). Activity was observed as a detectable zone of hydrolysis after $48 \mathrm{~h}$ of incubation at $37^{\circ} \mathrm{C}$. Lipolytic activity was considered positive when the strain was able to hydrolyze at least one of triglycerides tested; otherwise it was classified as negative.

\section{Production of exopolysaccharide}

The EPS production was tested according to the qualitative method described by Knoshaug et al. (2000). Strains were grown in MRS agar medium or LAPTg agar medium and incubated for $24 \mathrm{~h}$ at $37^{\circ} \mathrm{C}$. Ropiness of colonies on agar surfaces was tested with a loop to observe the formation of slimy filaments.

\section{Production of gas $\left(\mathrm{CO}_{2}\right)$}

The method described by Gibson \& Abd-El-Malek (1945) was used to test the ability to produce gas from glucose.

\subsection{Strain selection}

A multivariate analysis was performed on the 66 strains under study, in order to make a pre-selection of LAB to be included in the starter culture technological tests. Data were analyzed using cluster analysis non-hierarchical (K-means) in order to detect possible groupings between samples; the elements belonging to the same group are similar to each other. Cluster analysis were applied to technological properties and metabolic activities of LAB by using STATISTICA software (statistical packet Release 6.0 by Statsoft, Inc. 2001-Tulsa USA) (Tsukamura, 1976; Serrano \& Sandoval, 2008; Milesi 2008; Frau, 2011).

\subsection{Antagonistic effects}

The LAB cultures were tested for antagonistic activity against each other by the plate diffusion assay (Collins et al., 2004). Overnight cultures grown in MRS or LAPTg were washed twice with saline solution and suspended at the initial volume. Plates were prepared by pouring $15 \mathrm{~mL}$ of MRS soft agar containing $60 \mu \mathrm{L}$ of the cell suspension on the agar. After overlay solidification, $5 \mathrm{~mm}$ diameter wells made with sterilized plastic straws were inoculated with $60 \mu \mathrm{L}$ of culture from the other strains. After incubation at $37^{\circ} \mathrm{C}$ for $16 \mathrm{~h}$, appearance of inhibition zones were observed. The absence of zones of clearing around the wells were interpreted as compatible strains (negative) and the presence of zones of clearing around the wells were interpreted as incompatible strains (positive).

\subsection{Genotypic identification of selected strains}

The selected LAB strains were identified by $16 \mathrm{~S}$ rRNA gene sequencing analysis. Genomic DNA from the strains was extracted and the 16S rRNA gene amplification was performed using a genomic DNA sample as template and following universal primer pairs; 27F (5' AGAGTTTGATCCTGGCTCAG 3') and 1492R (5' GTTTACCTTGTTACGACTT 3'). The 16S rRNA sequences were aligned and compared with other 16S rRNA genes using the NCBI Basic Local Alignment Search Tools, nucleotide (BLASTn) program (Ribosomal Database Project, 2016; National Institutes of Health, 2016).

\subsection{Pathogenic properties of enterococci strains}

\section{Production of hemolysin}

The production of hemolysin was determined, according to the method described by Abeijón (2004). Enterococci selected strains cultures were streaked on blood agar plates and incubated 
for $24-48 \mathrm{~h}$ at $37{ }^{\circ} \mathrm{C}$. The presence or absence of clear zones around the colonies was interpreted as beta-hemolysis (positive) or gamma-hemolysis (negative) activity, respectively.

\section{Detection of gelatin hydrolysis}

The gelatin hydrolysis by enterococci strains was determined according to the method described by Abeijón (2004). All isolates were grown overnight on trypticase soy agar plates during $48 \mathrm{~h}$ at $37^{\circ} \mathrm{C}$ or 5 days at $4{ }^{\circ} \mathrm{C}$ before examination for zone of turbidity around the colonies indicating hydrolysis of gelatin.

\section{Antibiotics resistant test}

Antibiotic discs (Britania S.A.) were used to determine the susceptibility of the strains to vancomycin $(30 \mu \mathrm{g})$ and teicoplanin $(30 \mu \mathrm{g})$. The discs were placed onto Mueller-Hinton agar plates with enterococci culture. After incubation for $24 \mathrm{~h}$ at $37^{\circ} \mathrm{C}$ the diameter of inhibition haloes around the colonies was measured (Abeijón, 2004).

\subsection{Spreadable cheese manufacture}

On the basis of cluster analysis and strains compatibility test, selected strains were combined in different proportions and used as starter culture for spreadable cheese manufacture. Goat milk was collected in glass jars, cooled $\left(4^{\circ} \mathrm{C}\right)$, and carried to the laboratory. Cheeses were manufactured according to the protocols of Frau (2011). Sterile flasks were filled with goat milk $(500 \mathrm{~mL})$ to be pasteurized at $75^{\circ} \mathrm{C}$ for $30 \mathrm{~min}$. After cooling to $37^{\circ} \mathrm{C}$, sterile calcium chloride $(0.035 \mathrm{~g} / \mathrm{L}$ of milk) was added and each batch was inoculated with $1 \%(\mathrm{v} / \mathrm{v})\left(10^{7} \mathrm{CFU} / \mathrm{mL}\right)$ culture of ten different combinations of strains. Inoculated milk was then incubated at $37^{\circ} \mathrm{C}$ until the pH dropped to 6.2. At this point, liquid bovine rennet was added. Coagulation time was controlled by rocking and turning the bottles gently to test casein adhesion to their sides. Clotting took place in $40 \mathrm{~min}$; after this procedure cheese curds were salted $(1.5 \%$ of the milk weight) and drained in cheese cloth at $30{ }^{\circ} \mathrm{C}$ until $\mathrm{pH} \leq 5$. Cheeses were vacuum packed at $75 \mathrm{mb}$ into $100 \mu \mathrm{m}$ polyethylene bags and matured at $5{ }^{\circ} \mathrm{C}$ for 7 days. Cheeses manufactured with commercial starter (commercial starter culture Diagrama SLB 95) were used as control.

\subsection{Sensory analysis}

Sensorial attributes of cheese (oral and visual texture, odor, spreadability, flavor, aftertaste and general acceptance) were evaluated by a non-trained panel (30 tasters) using a qualitative hedonic scale of 5 points: 1 : dislike very much; 2 : dislike moderately; 3: neither dislike nor like; 4: like moderately; and 5: like very much (Valencia et al., 2008; Nepote et al., 2008; Pastor et al., 2008; Obando et al., 2010). The tasters were from Santiago del Estero (Argentina); 15 women and 15 men from 25 to 55 years who are regular consumers of goat chesses. For sample evaluation, each taster received 5 samples in plastic spoons coded with letters; between samples every consumer should eat a cookie to clear their palate (Nepote et al., 2008; Pastor et al., 2008; Obando et al., 2010). Comparisons were accomplished by ANOVA general linear model followed by Tukey's post-hoc test, and $\mathrm{p}<0.05$ was considered significant.

\subsection{Rheological measurements}

Cheese samples were gently stirred 10 times by spoon prior to rheological analysis. Rheological measurements were done in triplicate on all samples. Flow curves were obtained using a TA Instruments AR 1000 Rheometer (TA Instruments, New Caste, USA) fitted with a Couette measuring geometry $(25 \mathrm{~mm}$ diameter). The temperature was maintained at $25^{\circ} \mathrm{C}$. Each sample was measured by small amplitude oscillation within its linear viscoelastic region by imposing fixed amplitude displacement and varying the angular frequency, $\left(\mathrm{s}^{-1}\right)$, of the displacement (Hassan et al., 2003; Kealy, 2006).

\subsection{Statistical analysis}

All assays were carried out in triplicate, and results were expressed as mean values with standard deviations. Statistical analyses were performed using STATISTICA software (statistical packet Release 6.0 by Statsoft, Inc. 2001-Tulsa USA). Comparisons were accomplished by ANOVA general linear model followed by Tukey's post-hoc test, and $\mathrm{p}<0.05$ was considered significant.

\section{Results and discussion}

\subsection{Technological properties and metabolic activities of LAB}

\section{Acidifying activity}

The results revealed that acidifying activity of lactobacilli strains was higher than the activity of lactococci $(\mathrm{p}<0.05)$ (Table 1). Lactobacilli showed greater acidifying capacity $(89.6 \%$ of the strains evaluated) (milk coagulation $<16 \mathrm{~h}$ ) compared to lactococci (13.8\% of the strains evaluated). Within the group of lactobacilli characterized as "fast" one of the strains (b4) (pH: 3.78) was more prominent.

It was observed that $13.89 \%$ of lactococci were characterized as fast and $61.11 \%$ as slow (milk coagulation $>16 \mathrm{~h}$ ). A high percentage of the strains (25\%) were unable to coagulate milk.

Table 1. Technological properties and metabolic activities of LAB.

\begin{tabular}{|c|c|c|c|}
\hline \multirow{2}{*}{ Property } & \multirow{2}{*}{ Classification } & \multicolumn{2}{|c|}{$\%$ Strain } \\
\hline & & Lactobacilli & Lactococci \\
\hline \multirow{3}{*}{ Acidifying Activity } & Fast & 89.66 & 13.89 \\
\hline & Slow & 10.34 & 61.11 \\
\hline & Not coagulate & 0 & 25 \\
\hline \multirow{3}{*}{ Proteolytic activity } & High & 10.34 & 13.51 \\
\hline & Regular & 82.76 & 83.78 \\
\hline & Low & 6.90 & 2.70 \\
\hline \multirow{3}{*}{$\begin{array}{l}\text { Diacetyl-acetoin } \\
\text { production }\end{array}$} & High & 6.90 & 8.11 \\
\hline & Regular & 31.03 & 40.54 \\
\hline & Non-producing & 62.07 & 51.35 \\
\hline \multirow{2}{*}{ Citrate Utilization } & Positive & 37 & 32 \\
\hline & Negative & 63 & 68 \\
\hline \multirow{2}{*}{ Lipolityc activity } & Positive & 17.39 & 67.57 \\
\hline & Negative & 82.61 & 32.43 \\
\hline Production of & Positive & 6 & 0 \\
\hline Exopolysaccharide & Negative & 94 & 100 \\
\hline \multirow{2}{*}{$\begin{array}{l}\text { Production of gas } \\
\left(\mathrm{CO}_{2}\right)\end{array}$} & Positive & 41.38 & 10.81 \\
\hline & Negative & 58.62 & 89.19 \\
\hline
\end{tabular}


A rapid decrease in $\mathrm{pH}$ during the initial steps of cheese manufacture is crucial, as it is essential for coagulation and prevention or reduction of adventitious microflora growth (Ayad et al., 2004). The highest acidifying activity of lactobacilli strains with respect to lactococci was reported by other authors (Ayad, 2001; Ayad et al., 2004). The varying acidities observed between different strains were explained by De Roissart (1986). Indeed, the acidifying aptitude characterizes each isolate because it is related to the particular aptitudes which each have to degrade the compounds of the medium, to make them more assimilable and to transport the nutritive elements in the cytoplasm. In addition, the differences are due to a deficiency in the transport system of the nutritive substances of fermentable sugars (Albenzio et al., 2001).

\section{Proteolytic activity}

The proteolytic activity of lactobacilli and lactococci observed was similar $(\mathrm{p}>0.05)$ in groups, predominating regular (from 4 to $1.1 \mathrm{mM}$ glycine/L milk) and low activity (< $1 \mathrm{mM}$ glycine/L milk) (Table 1). Morishita et al. (1981) and Requena et al. (1991) found higher proteolytic activity in lactobacilli rather than lactococci; while Dako et al. (1995) reported similar results to those in this work.

The degradation of casein has an important role in the development of texture in cheese. In addition, some peptides contribute to the development of flavor, whereas other undesirable bitter tasting peptides can lead to off-flavor formation. Bacterial cell wall associated proteases and intracellular peptidases released after cell lysis in the curd are considered to play an important role in casein hydrolysis during cheese preparation (Wilkinson et al., 1994).

\section{Diacetyl-acetoin production}

The ability to produce aroma compounds (diacetyl and acetoin) observed in lactobacilli and lactococci was similar $(\mathrm{p}>0.05)$. Diacetyl and acetoin have very distinct aroma properties and significantly influence the quality of fermented foods (Hugenholtz, 1993). For instance, diacetyl determines the aromatic properties of fresh cheese, fermented milk, cream, and butter (De Figueroa et al., 1998). Spreadable cheese is a product ready for consumption at the end of the manufacture process, so it is then necessary to incorporate strains capable of producing aroma compounds, especially diacetyl (Van Kranenburg et al., 2002; Barron et al., 2005).

\section{Citrate utilization}

The study of the ability of the strains to use citrate as a carbon source showed that an equal percentage (37\%) of lactobacilli and lactococci were able to metabolize citrate (Table 1). The ability to metabolize citrate is an important technological characteristic of some starter lactic acid bacteria. Citrate in milk is metabolized by many species of LAB into flavor compounds, such as diacetyl, acetoin, and 2,3-butanediol (Hugenholtz, 1993; Axelsson, 1998). Although the citrate concentration in milk is low (approximately $8 \mathrm{mM}$ ), the ability of LAB to metabolize and produce aromatic compounds gives this trains an important role in fermented products such as butter, milk and some cheeses.

\section{Lipolytic activity}

The results obtained reveal that the lipolytic activity of lactococci strains was significantly higher than the activity of the lactobacilli; these results agree with those reported by Savoy (1983). Milk fat hydrolysis during cheese manufacture and ripening occurs due to factors such as endogenous milk lipase, lipolytic enzymes of starter and non-starter bacteria, lipases from psychrotrophic bacteria, and depending on the cheese variety, exogenous enzyme preparations. Released fatty acids contribute to cheese flavor (Collins et al., 2003).

\section{Production of exopolysaccharide (EPS)}

Of all the strains tested, only four lactobacilli were able to produce exopolysaccharide (EPS+). Non-producing strains are indicated in this work as EPS-.

Many factors such as the source of carbon and energy, milk composition, incubation temperature, pasteurization conditions and acidity could influence the synthesis of EPS (Alais, 2003). These cultures will be evaluated for their ability to improve the texture of cheese in future studies.

\section{Production of gas $\left(\mathrm{CO}_{2}\right)$}

Table 1 shows the percentages of each group capable of producing gas. For spreadable cheese manufacture, producing gas strains is not desirable.

\subsection{Strain selection}

Cluster analysis was applied to technological properties and metabolic activities of lactobacilli (Figure 1). This study grouped the strains into six statistical groups: Group 1 (EPS+ strains); Group 2 (one strain with high proteolitic activity), Group 3 (strains with fast acidifying activity), Group 4 (one strain with fast acidifying activity and high acid production), Group 5 (one strain capable of producing gas) and Group 6 (strains without important properties). From the clusters it was clear that some of the strains differed significantly from each other. It is interesting to note that strains b23, b4 and b2 are different from the other strains. The rest of the strains were clustered in two large groups (group 3 and 6). Based on these results, strains of groups 3, 5 and 6 were eliminated from the study.

For compatibility studies and formulation of starter, the strains b23, b22 and b4 were selected.

Cluster analysis was also applied to technological properties and metabolic activities of lactococci (Figure 2). These strains were grouped into four statistical groups: Group 1 (one strain high proteolitic and acidifying activities and diacetyl-acetoin production), Group 2 (strains with high diacetyl-acetoin production and moderate proteolitic activity), Group 3 (strains without important properties) and Group 4 (one strain with moderate proteolitic activity and capable of producing gas). From the clusters it was clear that some of the strains differed 


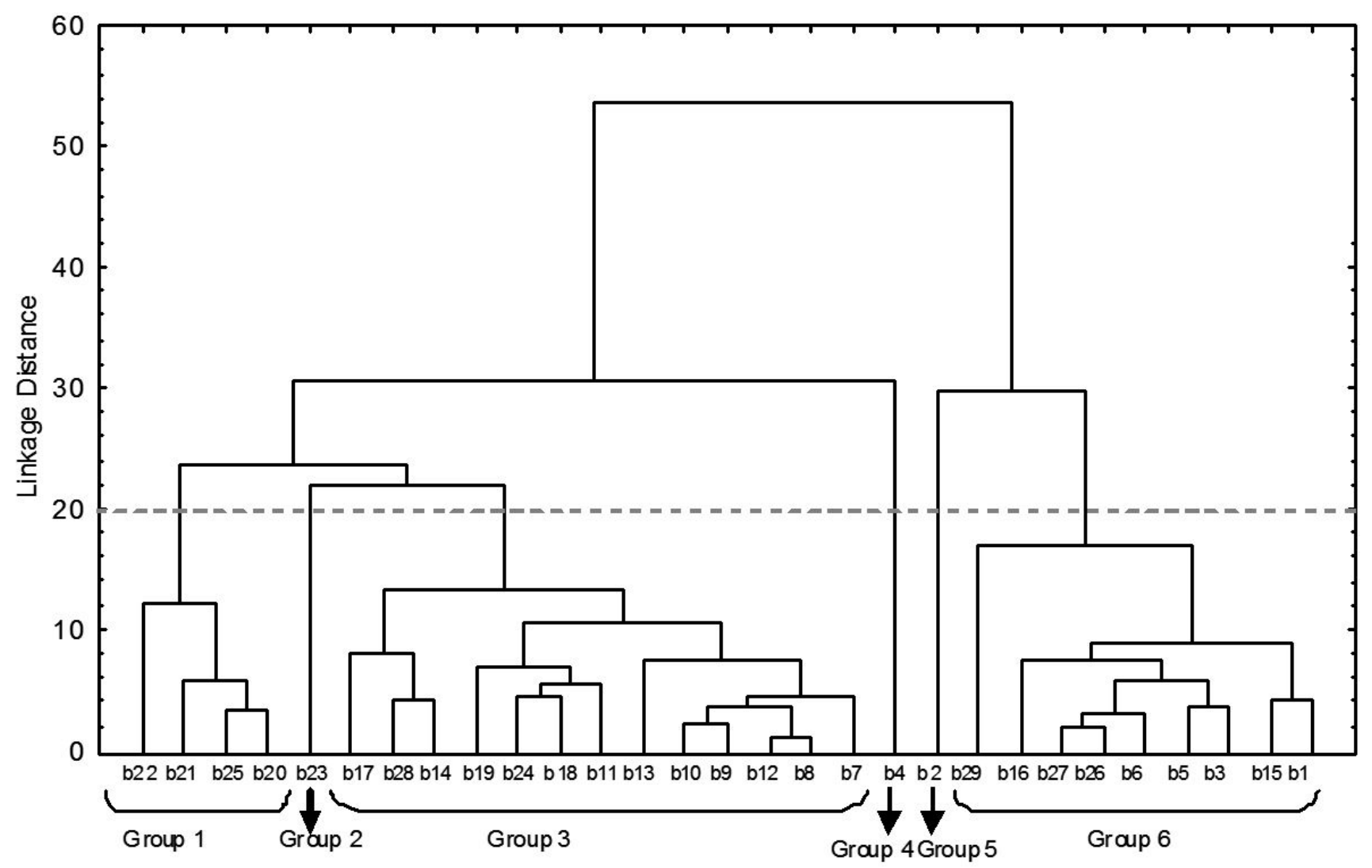

Figure 1. Cluster analysis on technological properties and metabolic activities of lactobacilli.

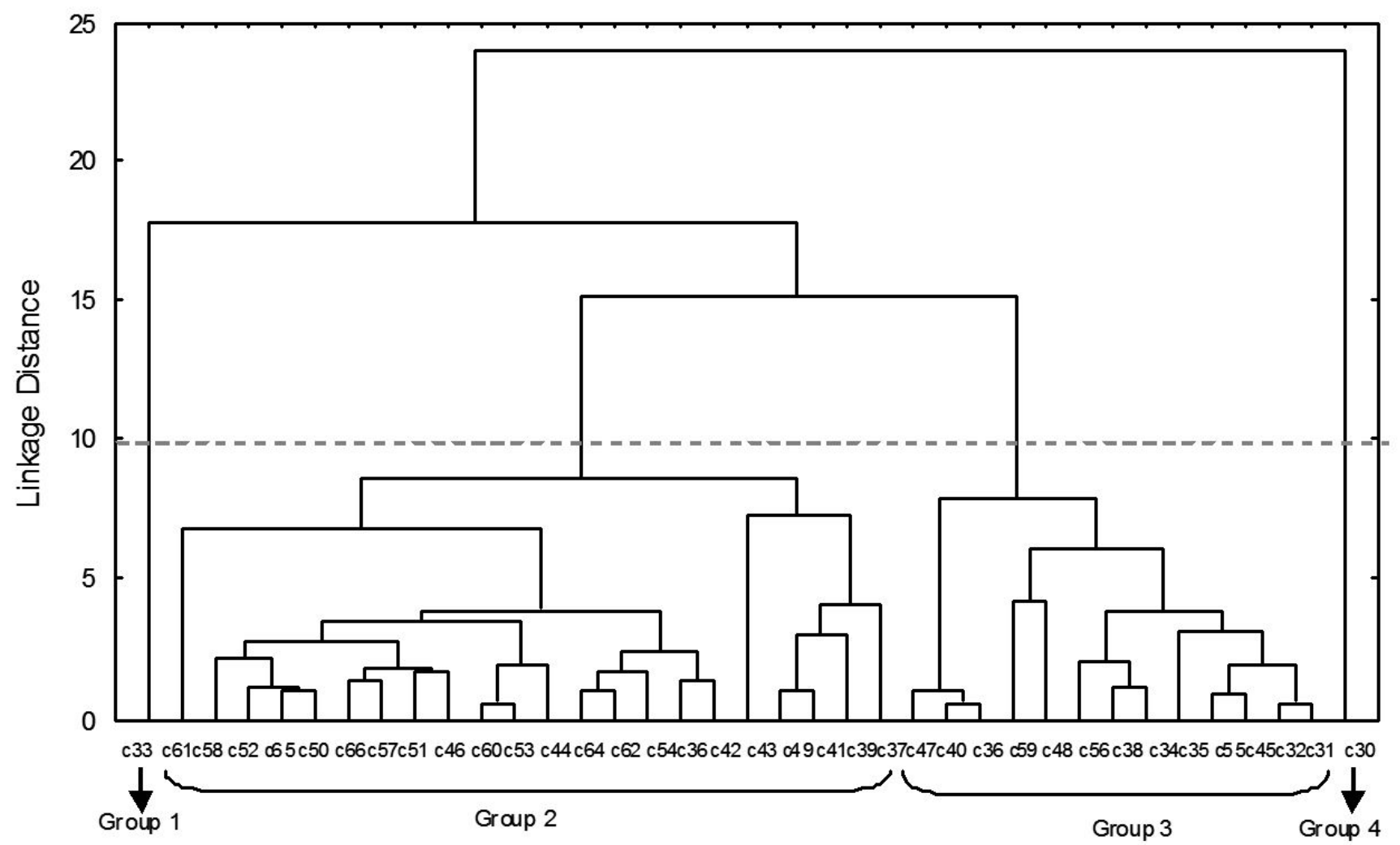

Figure 2. Cluster analysis on technological properties and metabolic activities of lactococci. 
significantly from each other, such as c 33 and c 30 . Based on these results, strains of groups 3 and 4 were eliminated from the study.

For compatibility studies and formulation of starter, the strains c33 and c55 were selected; c55 was selected because it showed the highest production of aroma compounds within Group 2.

\subsection{Antagonistic effects}

When selecting mixed cultures, potential antagonisms must also be ascertained. It is well known that LAB produces bacteriocins that can inhibit the growth of other starter strains and thus compromise the fermentation process (Klaenhammer, 1988). Consequently, it was deemed necessary to evaluate the selected pure cultures with respect to potential antagonisms before using them in further assays. Compatibility of selected strains (b23, b4, b22, c33 and c55) was studied using the agar diffusion method. c33 showed inhibition of the other selected strains, consequently it was eliminated from the study.

Based on these results, four strains were selected for starter culture: b4 (lactobacillus with high acidifying activity), b23 (lactobacillus with high proteolytic activity), b22 (lactobacillus with production of exopolysaccharide) and c55 (lactococcus with diacetyl-acetoin production). The four strains selected were identified (using molecular studies) and coded in CERELA-CONICET collection as: b4, (Lactobacillus fermentum) CRL1799; b23, (Lactobacillus fermentum) CRL1803; b22, (Lactobacillus rhamnosus) CRL1808; c55, (Enterococcus faecium) CRL1785.

\subsection{Pathogenic properties of enterococci strain}

As CRL1785 (c55) was identified as Enterococcus faecium, it was necessary to test it for pathogenicity. This strain did not hydrolyze gelatin, did not produce hemolysis on blood media and presented no reference antibiotic (vancomycin and teicoplanin) resistance.

Andrighetto et al. (2001) found that only one of 124 strains isolated from dairy products showed high resistance to vancomycin and teicoplanin. This finding suggests that resistance to these antibiotics is uncommon among strains isolated from dairy products. These results indicate that Enterococcus faecium CRL1785 could be useful as adjunct cultures in spreadable cheese manufacture.

\subsection{Spreadable cheese manufacture, sensory analysis and rheological measurements}

To formulate the starter, three models of working were performed in batch by duplicate:

a) Test without EPS producing strain (EPS-): Using as ferment different combinations of CRL1799, CRL1803 and CRL1785 ( 2 and 3 strains in different proportions).

b) Test with EPS producing strain (EPS+): Using combinations of A), with the addition of CRL1808 in different proportions.

c) Control Test with commercial starter culture.

In this study only the combinations with the higher sensory score are presented (Table 2). The number shown in Table 2 represents the score obtained by each combination of strains on a five-point hedonic scale. Statistical analysis indicated the existence of significant differences $(\mathrm{p}<0.05)$ between EPS+ combinations with both EPS- and commercial starter culture.

The low score of the EPS- samples is mainly due to defects in visual, oral texture and spreadability (Table 2). If any of the EPS- combinations are used, it will be necessary to incorporate additives to improve texture and spreadability.

The low score obtained in the commercial starter culture was due to taste and aftertaste; the product was rejected by its extreme acidity and not having the typical flavor expected for goat cheese. The lack of typical flavor when using the commercial starter culture indicates the importance of the incorporation autochthonous starter culture that enables the development of typical flavor compounds.

The highest score was obtained with the EPS +A combination, containing CRL1799, CRL1803, CRL1785, and CRL1808 in the ratio $1: 1: 1: 3$.

In the general comments made by the panelists, the experimental cheeses had a great acceptance with reference to qualities such as acceptable texture, pleasant and typical goat flavor.

With the addition of the EPS + strain it was possible to obtain the expected textural characteristics, without the incorporation of additives. The positive effect of EPS+ strain is due to the important role of EPS as natural thickeners that improve the

Table 2. Mean score of attribute for chesses manufacture with different autochthonous or commercial starter culture.

\begin{tabular}{|c|c|c|c|c|}
\hline \multicolumn{2}{|c|}{ Model } & Combination & Ratio & Sensory Score \\
\hline \multirow{4}{*}{ EPS- } & A & CRL1799 + CRL1803 + CRL1785 & $1: 1: 1$ & 2.00 \\
\hline & $\mathrm{B}$ & CRL1799 + CRL1803 + CRL1785 & $2: 1: 1$ & 3.00 \\
\hline & $\mathrm{C}$ & CRL1799 + CRL1803 + CRL1785 & $1: 2: 1$ & 2.74 \\
\hline & $\mathrm{D}$ & CRL1799 + CRL1803 + CRL1785 & $1: 1: 2$ & 2.70 \\
\hline \multirow{4}{*}{ EPS+ } & A & CRL1799 + CRL1803 + CRL1785 + CRL 1808 & $1: 1: 1: 3$ & 4.60 \\
\hline & $\mathrm{B}$ & CRL1799 + CRL1803 + CRL1785 + CRL 1808 & $2: 1: 1: 3$ & 3.80 \\
\hline & $\mathrm{C}$ & CRL1799 + CRL1803 + CRL1785 + CRL 1808 & $1: 2: 1: 3$ & 3.50 \\
\hline & $\mathrm{D}$ & CRL1799 + CRL1803 + CRL1785 + CRL 1808 & $1: 1: 2: 3$ & 2.90 \\
\hline & & Commercial starter culture & $1 \%$ & 2.00 \\
\hline
\end{tabular}


rheology of fermented products and as physical stabilizers, allowing water binding and preventing syneresis.

The rheological behavior of EPS+A, EPS-A and commercial samples as a function of frequency is presented in Figures 3 and 4. All samples exhibited characteristics typical of a weak viscoelastic gel, with G' greater than G', this behavior was observed in all cheeses. The elastic component contributes more viscoelasticity $\left(G^{\prime}>G^{\prime \prime}\right)$, which leads to a structure resembling more of a solid within the range of frequencies studied, which was also noted by other authors (Messens et al., 2002; San Martín-González et al., 2007). The rise of G' with frequency $(\omega)$ might be due to casein particle fusion as a consequence of the rearrangement of inter- and intra-molecular forces, which in turn results in an increased contacting surface among the casein aggregates; and possibly

\section{$\mathbf{G}^{\prime}(\mathbf{P a})$}

to the additional particles added to the web (Roefs et al., 1990; Van Vliet, 2000; Hernández-Tinoco et al., 2004). The decrease in the number of interactions among the protein aggregates due to the presence of EPS in the continuous phase surrounding them were likely to contribute to the smaller G' and G" values for the EPS+ cheeses in comparison with the EPS- throughout the entire range of frequencies under study (i.e. 1-100 Hz), which is coincident with results of other authors in studies of Hassan et al. (2003).

Cheese rheology matches with sensory analysis, indicating that sensory texture and general appearance of EPS+ cheeses were significantly better than EPS- cheeses.

These results indicate that the inclusion of EPS+ strain improve the rheology and texture of spreadable goat cheese

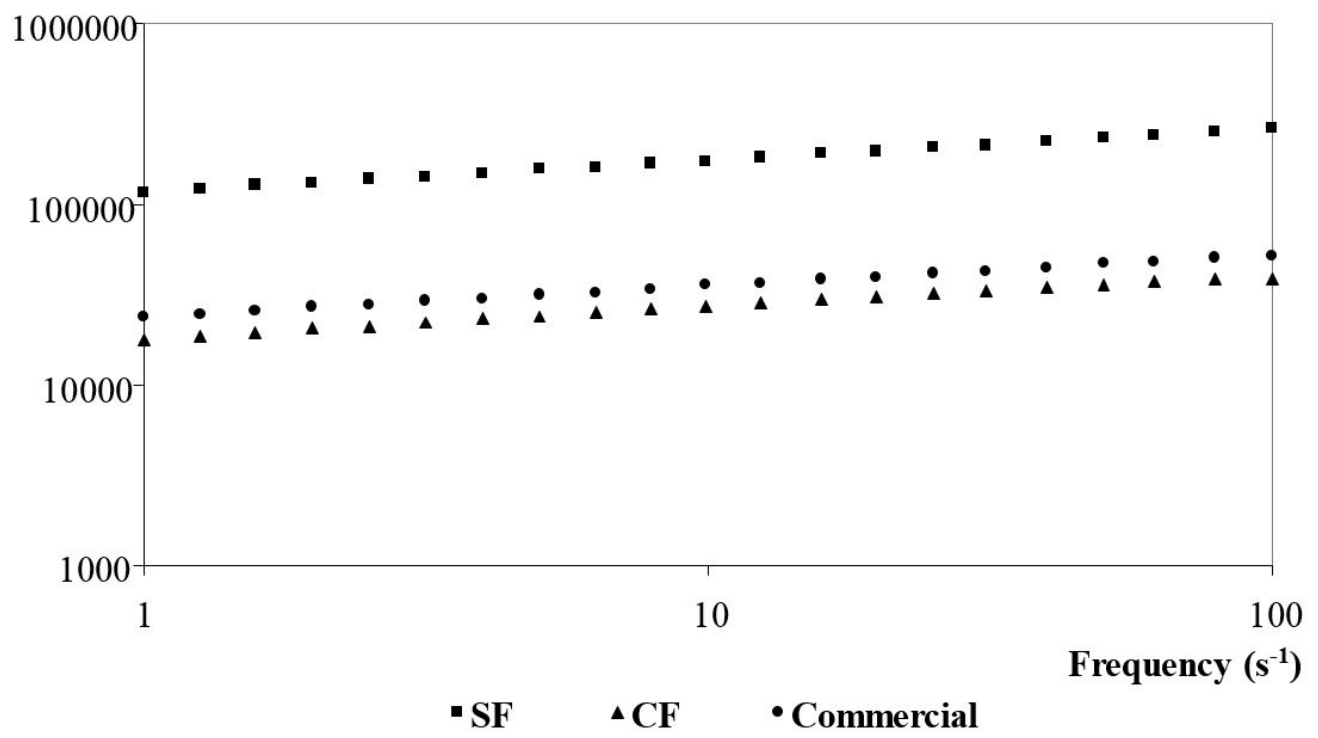

Figure 3. G' variation with frequency in EPS+, EPS- and commercial samples.

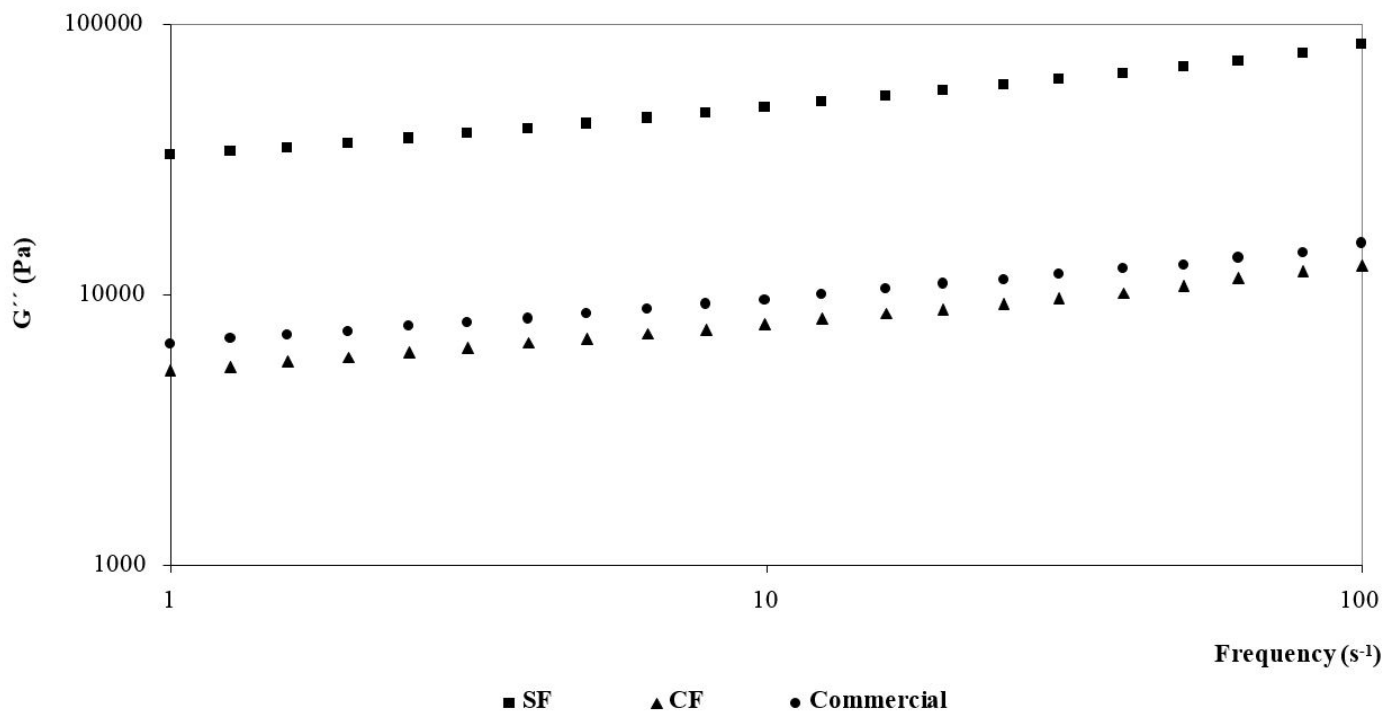

Figure 4. G" variation with frequency in EPS+, EPS- and commercial samples. 


\section{Conclusions}

Several LAB strains autochthonous from Santiago del Estero isolated from dairy goats showed properties useful as starter or adjunct cultures in the production of dairy goat products. The four selected strains showed qualities adequate for use as starter culture in the elaboration of spreadable cheese from the point of view of their biotechnological properties, safety and compatibility. The starter culture developed in this paper is an alternative to obtain comparative advantages and to obtain differentiated products. The inclusion of EPS + strain clearly improved the rheology and texture of spreadable cheese.

Cheese industry is looking for new types of LAB starter-cultures; thus, the use of this autochthonous starter culture could prevent the loss of the typical and exclusive organoleptic properties in goat cheeses improving their quality.

\section{References}

Abeijón, C. (2004). Rol de enterococos en el desarrollo de compuestos de aroma y sabor durante el proceso de maduración de quesos de oveja del noroeste argentino ( $\mathrm{PhD}$ thesis). Universidad Nacional de Tucumán, Tucumán. Retrieved from http://www.fediap.com. ar/administracion/pdfs/Agroalimentos\%20Argentinos\%20II\%20 -\%20AACREA.pdf

Alais, Ch. (2003). Ciencia de la leche (4th ed.). España: Reverté.

Albenzio, M., Corbo, M. R., Rehman, S. U., Fox, P. F., De Angelis, M., Corsetti, A., Sevi, A., \& Gobbetti, M. (2001). Microbiological and biochemical characteristics of Cane Strato Pugliese cheese made from raw milk, pasteurized milk or by heating the curd in hot whey. International Journal of Food Microbiology, 67(1-2), 35-48. http:// dx.doi.org/10.1016/S0168-1605(00)00533-X.

Andrighetto, C., Knijff, E., Lombardi, A., Torriani, S., Vancanneyt, M., Kersters, K., Swings, J., \& Dellaglio, F. (2001). Phenotypic and genetic diversity of enterococci isolated from Italian cheeses. The Journal of Dairy Research, 68(2), 303-316. http://dx.doi.org/10.1017/ S0022029901004800. PMid:11504393.

Axelsson, L. (1998). Lactic acid bacteria: classification and physiology. In S. Salminen \& A. von Wright, Microbiology and functional aspects (3rd ed.). New York: Marcel Dekker.

Ayad, E. (2001). Characterization of lactococci isolated from natural niches and their role in flavour formation of cheese ( $\mathrm{PhD}$ thesis). Wageningen Agricultural University, Wageningen.

Ayad, E., Nashat, S., El-Sadek, N., Metwaly, H., \& El-Soda, M. (2004). Selection of wild lactic acid bacteria isolated from traditional Egyptian dairy products according to production and technological criteria. Food Microbiology, 21(6), 715-725. http://dx.doi.org/10.1016/j. fm.2004.02.009.

Barritt, M. (1936). The intensification of the Voges Proskauer reaction by the addition of $\alpha$-naphthol. The Journal of Pathology and Bacteriology, 42(2), 441-454. http://dx.doi.org/10.1002/path.1700420212.

Barron, L. J. R., Redondo, Y., Flanagan, C. E., Pérez-Elortondo, F. J., Marta Albisu, Nájera, A. I., Renobales, M., \& Fernández-García, E. (2005). Comparison of the volatile composition and sensory characteristics of Spanish PDO cheeses manufactured from ewes' raw milk and animal rennet. International Dairy Journal, 15(4), 371-382. http://dx.doi.org/10.1016/j.idairyj.2004.08.005.

Blanco, L., Richardson, G., Sherbon, J., Biuque, J., Leman, D., Roth, W., Inn, R., \& Liden, D. (1978). Supplemental chemical control methods.
In Standard methods for the examination of dairy products (14th ed.). Washington: American Public Health Association.

Church, F., Swaisgood, H., Porter, D., \& Catignani, G. (1983). Spectrophotometric assay using o-phthaldialdheyde for determination of proteolysis in milk and isolated milk protein. Journal of Dairy Science, 66(6), 1219-1227. http://dx.doi.org/10.3168/jds.S00220302(83)81926-2.

Collins, C., Lyne, P., Granz, \& Falkinham, J. III (2004). Antimicrobial methods (8th ed.). London: Arnold, a member of the Hodder Headline Group.

Collins, Y., McSweeney, P., \& Wilkinson, M. (2003). Lipolysis and free fatty acid catabolism in cheese: a review of current knowledge. International Dairy Journal, 13(11), 841-866. http://dx.doi.org/10.1016/ S0958-6946(03)00109-2.

Dako, E., El-Soda, M., Vuillemard, J. C., \& Simard, R. E. (1995). Autolytic properties and aminopeptidase activities of lactic acid bacteria. Food Research International, 28(5), 503-509. http://dx.doi. org/10.1016/0963-9969(95)00032-1.

De Figueroa, R.M., Cerutti de Guglielmone, G., Benito de Cárdenas, I., \& Oliver, G. (1998). Flavour compound production and citrate metabolism in Lactobacillus rhamnosus ATCC 7469. Milchwissenschaft, 53(11), 617-619.

De Roissart, H. B. (1986). Bacteries lactiques. In F. M. Luquet. Laits et produits laitiers: vache, brebis et chevre Tome 3. France: Technique et Documentation Lavoisier.

El-Soda, M., El-Ziney, M., Awad, S., Osman, G., Omran, N., Gamal, G., Ezzat, N., \& El-Shafei, H. (2003). A culture collection of lactic acid bacteria isolated from raw milk and traditional Egyptian dairy products. Journal of Dairy Science, 31, 23-41.

Frau, F. (2011). Desarrollo de quesos untables de cabra usando fermentos lácticos autóctonos, como estrategia tecnológica para la cuenca caprina de Santiago del Estero ( $\mathrm{PhD}$ thesis). Universidad Nacional de Santiago del Estero, Santiago del Estero.

Galeslod, T. E., Hassing, F., \& Stadhouuders, J. (1961). Agar medium for the isolation and enumeration of aroma bacteria in starters. Netherlands Milk and Dairy Journal, 15, 127-129.

Gibson, T., \& Abd-El-Malek, Y. (1945). The formation of carbon dioxide by lactic acid bacteria and Bacillus licheniformis and a cultural method of detecting the process. The Journal of Dairy Research, 14(1-2), 3538. http://dx.doi.org/10.1017/S0022029900032295.

Hassan, A. N., Ipsen, R., Janzen, T., \& Qvist, K. (2003). Microstructure and rheology of yogurt made with cultures differing only in their ability to produce exopolysaccharides. Journal of Dairy Science, 86(5), 1632-1638. http://dx.doi.org/10.3168/jds.S0022-0302(03)73748-5. PMid:12778573.

Hernández-Tinoco, A., Ramos-Ramírez, E., Falcony-Guajardo, C., \& Salazar-Montoya, A. A. (2004). Rheometry and scanning electron microscopy study of casein curds added with mequite seed gum and soy proteins. Latin American Applied Research, 34, 195-202.

Hugenholtz, J. (1993). Citrate metabolism in lactic acid bacteria. Microbiological Reviews, 12(1-3), 165-178. http://dx.doi. org/10.1111/j.1574-6976.1993.tb00017.x.

Jaeger, K. E., \& Eggert, T. (2002). Lipases for biotechnology. Current Opinion in Biotechnology, 13(4), 390-397. http://dx.doi.org/10.1016/ S0958-1669(02)00341-5. PMid:12323363.

Kealy, T. (2006). Application of liquid and solid rheological technologies to the textural characterization of semi-solid foods. Food Research International, 39(3), 265-276. http://dx.doi.org/10.1016/j. foodres.2005.07.016. 
Klaenhammer, T. R. (1988). Bacteriocins of lactic acid bacteria. Biochimie, 70(3), 337-349. http://dx.doi.org/10.1016/0300-9084(88)90206-4. PMid:3139051.

Knoshaug, E. P., Ahlgren, J. A., \& Trempy, J. E. (2000). Growth associated exopolysaccharide expression in Lactococcus lactis subspecies cremoris Ropy352. Journal of Dairy Science, 83(4), 633-640. http:// dx.doi.org/10.3168/jds.S0022-0302(00)74923-X. PMid:10791777.

Kodali, V. P., Das, S., \& Sen, R. (2009). An exopolysaccharide from a probiotic: biosynthesis dynamics, composition and emulsifying activity. Food Research International, 42(5-6), 695-699. http://dx.doi. org/10.1016/j.foodres.2009.02.007.

Messens, W., Van de Walle, D., Arevalo, J., Dewettinck, K., \& Huyghebaert, A. (2002). Rheological properties of high-pressure-treated Gouda cheese. International Dairy Journal, 10(5/6), 359-367.

Milesi, M. M. (2008). Desarrollo de fermentos adjuntos para quesería a partir de bacterias lácticas no pertenecientes al fermento ( $\mathrm{PhD}$ thesis). Universidad Nacional del Litoral, Santa Fé.

Morishita, T., Deguchi, Y., Yajima, M., Sakurai, T., \& Yura, T. (1981). Multiple nutritional requirements of lactobacillus: genetic lesions affecting amino acids biosynthetic pathways. Journal of Dairy Bacteriology, 148(1), 64-71. PMid:6793557.

National Institutes of Health - NIH. (2016). Basic Local Alignment Search Tool. Bethesda: NIH. Retrieved from http://www.ncbi.nlm. nih.gov/BLAST

Nepote, V., Mestrallet, M. G., Olmedo, R. H., Ryan, L. C., Conci, S., \& Grosso, N. R. (2008). Chemical composition and sensory analysis of roasted peanuts coated with prickly pear and algarrobo pod syrups. Grasas y Aceites, 59(2), 174-181. http://dx.doi.org/10.3989/ gya.2008.v59.i2.507.

Nieto-Arribas, P., Seseña, S., Poveda, J. M., Palop, L., \& Cabezas, L. (2009). Genotypic and technological characterization of Lactococcus lactis isolates involved in processing of artisanal Manchego cheese. Journal of Applied Microbiology, 107(5), 1505-1517. http://dx.doi. org/10.1111/j.1365-2672.2009.04334.x. PMid:19426262.

Obando, C. M., Brito, C. S., Schöbits, R., Baez, L. A., \& Horzella, M. (2010). Viabilidad de los microorganismos probióticos Lactobacillus casei 01, Lactobacillus acidophilus La-5, Bifidobacterium BB12 durante el almacenamiento de queso cottage. Vitae, 17(2), 141-148.

Pastor, L. F. J., Mellado, B. M., Ramírez, A. A. \& Dolores R. E. (2008). Evaluación sensorial de queso de leche de cabra tipo Boursin sabor natural y ceniza (Sensory evaluation of goat milk cheese type boursin natural and ash flavor). Revista Electrónica de Veterinaria, 9(8), 1695-7504.
Raibaud, P., Galpin, J. V., Duclezeau, R., Mocquot, G., \& Oliver, G. (1973). Le Genre Lactobacillus dans le tube digestif du rat. II. Caracters de souches heterofermentaires isolates de rats. "holo" et "gnotoxeniques". Annalles de Microbiol, 124, 2223-2235.

Requena, T., Pelaez, C., \& Desmazeaud, M. (1991). Characterization of Lactococci and Lactobacilli isolated from semi-hard goat's cheese. The Journal of Dairy Research, 58(01), 137-145. http://dx.doi. org/10.1017/S0022029900033586.

Ribosomal Database Project - RDP. (2016). Michigan: Michigan State University. Retrieved from http://rdp.cme.msu.edu/html/analyses.html

Roefs, S. P. F. M., de Groot-Mostert, A. E. A., \& van Vliet, T. (1990). Structure of acid casein gels. Formation and model of gel network. Colloids and Surfaces, 50, 141-159. http://dx.doi.org/10.1016/01666622(90)80259-7.

San Martín-González, M. F., Rodríguez, J. J., Gurram, S., Clark, S., Swanson, B. G., \& Barbosa-Cánovas, G. V. (2007). Yield, composition and rheological characteristics of cheddar cheese made with high pressure processed milk. LWT - Food Science and Technology, 40(4), 697-705. http://dx.doi.org/10.1016/j.lwt.2006.03.022.

Sandine, W. E. (1979). Lactic starter culture technology. New York: Pfizer.

Savoy, G. (1983). Comportamiento de fermentos regionales aplicados a la industria lechera (PhD thesis). Universidad Nacional de Tucumán, Tucumán.

Serrano, R., \& Sandoval, J. (2008). Identificación y diagnóstico de actinomicetales patógenos. Venezuela: Saber-Ula.

Tsukamura, M. (1976). An approach to numerical identification of bacterial species. Journal of General Microbiology, 95(2), 207-212. http://dx.doi.org/10.1099/00221287-95-2-207. PMid:956783.

Valencia, G. E., Millán, C. L., \& Jaramillo, G. Y. (2008). Estimación de la vida útil fisicoquímica, sensorial e instrumental de queso crema bajo en calorías. Revista Lasallista de Investigación, 5(1), 28-33.

Van Kranenburg, R., Kleerebezem, M., van Hylckama Vlieg, J., Ursing, B. M., Boekhorst, J., Smit, B. A., Ayad, E. H. E., Smit, G., \& Siezen, R. J. (2002). Flavour formation from amino acids by lactic acid bacteria: predictions from genome sequence analysis. International Dairy Journal, 12(2-3), 111-121. http://dx.doi.org/10.1016/S09586946(01)00132-7.

Van Vliet, T. (2000). Structure and rheology of gels formed by aggregated protein particles. Hydrocolloids, Part 1. Amsterdam: Elsevier Science.

Wilkinson, M., Guinee, T., O'Callaghan, D., \& Fox, P. (1994). Autolysis and proteolysis in different strains of starter bacteria during Cheddar cheese ripening. The Journal of Dairy Research, 61(2), 249-262. http://dx.doi.org/10.1017/S0022029900028260. 